\title{
ANALISIS KINERJA KEUANGAN PERUSAHAAN DITINJAU DARI RENTABILITAS, LIKUIDITAS DAN SOLVABILITAS
}

\section{Hidayatul Mu'arifin dan Peri Irawan}

Universitas Pamulang Banten, Indonesia

Email: hidayatulmuarifin@gmail.com dan peri99irawan@gmail.com

\section{Abstract}

The purpose of this study is to analyze the financial performance of PT Sentul City Tbk and its Subsidiaries in 2018-2019 in terms of profitability, liquidity and solvency and to determine the effect of profitability, liquidity and solvency on Company Value both simultaneously and partially. The research object was carried out on the official website of PT Sentul City and at LQ45. The type of data used is secondary data. Methods of data collection using quantitative methods and descriptive methods, namely data in the form of exact numbers and analyze data from the company's financial statements. And it can be concluded that the level of analysis of profitability, liquidity and solvency is very influential on Firm Value and from the analysis the company can be categorized in a multi-state condition or not.

Keywords: liquidity; solvency; profitability; firm value

\begin{abstract}
Abstrak
Tujuan dari penelitian ini adalah untuk menganalisis kinerja keuangan PT Sentul City Tbk dan entitas anak pada tahun 2018-2019 ditinjau dari rentabilitas, likuiditas dan solvabilitas serta untuk mengetahui pengaruh rentabilitas, likuiditas dan solvabilitas terhadap nilai perusahaan baik secara simultan maupun parsial. Obyek penelitian dilaksanakan di website resmi PT Sentul City serta di LQ45. Jenis data yang digunakan adalah data sekunder. Metode pengumpulan data dengan menggunakan metode kuantitatif dan juga metode deskriptif yaitu data yang berbentuk angka pasti serta menganalisis data-data laporan keuangan dari perusahaan tersebut. Dapat diperoleh kesimpulan bahwa tingkat analisis dari rentabilitas, likuiditas dan solvabilitas sangat berpengaruh terhadap Nilai Perusahaan dan dari analisa trsebut perusahaan dapat dikategorikan dalam keadaan biak atau tidak.
\end{abstract}

Kata kunci: likuidtas; solvabilitas; rentabilitas; nilai perusahaan

Coresponden Author

Email: hidayatulmuarifin@gmail.com Artikel dengan akses terbuka dibawah lisensi 


\section{Pendahuluan}

Dunia usaha sering mengalami persaingan yang sangat tidak terduga entah dari segi barang yang diciptakan maupun dari segi kualitas barang yang dihasilkan dan juga bisa dikaitkan dengan seberapa perusahaan bisa konsisten berkambang. Nilai perusahaan juga menjadi salah satu tolak ukur untuk mengetahui seberapa baik perusahaan tersebut dalam mengelola finansialnya (Atmadjati, 2018).

Nilai perusahaan dapat diukur dengan beberapa rasio-rasio keuangan diantaranya rasio likuiditas, rasio solvabilitas dan rasio rentabilitas. Rasio likuiditas merupakan rasio yang digunakan untuk mengukur bagaimana kemampuan perusahaan dalam membayar kewajiannya dan rasio ini mengunakan nilai aktiva lancer dan hutang lancer. Rasio Solvabilitas merupakan rasio yang digunakan perusahaan untuk mengukur seberapa besar perusahaan bisa membayar hutangnya apabila perusahaan tersebut mengalami likuidasi dan pengukuran ini mengunakan nilai dari total harta hutang dan modal. Rasio Rentabilitas merupakan rasio yang digunakan untuk mengukur seberapa besar perusahaan memperoleh keuntungannya dengan mengunakan semua modal yang ada dan pengukuran ini mengunakan nilai laba kotor, pendapatan penjualan, pendapatan bersih maupun penjualan bersih (Pongoh, 2013).

Menurut (Agus Sartono, 2012) mengemukakan bahwa: "Likuiditas perusahaan, menunjukkan kemampuan untuk membayar kewajiban finansial jangka pendek tepat pada waktunya. Likuiditas perusahaan ditunjukkan oleh besar kecilnya aktiva lancar yaitu aktiva yang mudah untuk diubah menjadi kas yang meliputi kas, surat berharga, piutang, persediaan".

Menurut (Sutrisno, 2012) menyatakan bahwa: "Likuiditas adalah kemampuan perusahaan untuk memenuhi kewajiban-kewajibannya yang segera harus dipenuhi." Menurut (Kasmir, 2012) mengemukakan bahwa: "Rasio likuiditas atau sering juga disebut rasio modal kerja merupakan rasio yang digunakan untuk mengukur seberapa likuidnya suatu perusahaan."

Menurut (Budiawan, 2009) menyatakan bahwa yang mencerminkan kondisi kesehatan perusahaan dalam keadaan yang kurang baik mungkin disebabkan oleh beberapa faktor internal perusahaan, yang meliputi penurunan hasil penjualan, biayabiaya yang meningkat terutama biaya non usaha, kemampuan dalam membayar hutang harus tetap ditingkatkan dan pembelian aktiva yang digunakan perusahaan lebih ditujukan untuk kegiatan operasional. Sehingga untuk periode selanjutnya perusahaan harus memperhatikan faktor-faktor tersebut guna mencapai tujuan perusahaan sesuai dengan yang diharapkan.

Menurut (Saputra, 2019) menunjukkan bahwa kinerja keuangan pada PT HM SAMPOERNA Tbk di tahun 2015-2017 dilihat dari rasio likuiditas menggunakan current asset dinilai baik, selalu diatas $2 \mathrm{kali}$ atau di atas standar industi. Pada rasio solvabilitas menggunakan rasio Debt to Equity Ratio kinerja keuangan PT HM Sampoerna Tbk dinilai baik karena hasil dari rasio tersebut selalu dibawah standar industri sebesar 35\%. Rasio profitabilitas PT HM Sampoerna Tbk tahun 2015-2017 menggunakan Profit Margin on Sales dan Return on Equity kurang baik karena hasil 
perhitungan kedua rasio tersebut dibawah dari nilai standar industri untuk rasio profit margin on sales sebesar $20 \%$ sedangkan standar industri return on equity sebesar $30 \%$. Hasil rata-rata profit margin on sales tahun 2015-2017 sebesar 12,6\%, disebabkan karena laba bersih lebih sedikit dari penjualan. Rata-rata return on asset tahun 20152017 sebesar 28,88\%, disebabkan karena laba bersih lebih sedikit dari total asset. Ratarata return on equity tahun 2015-2017 sebesar 17,41\%, disebabkan karena laba bersih lebih sedikit dari modal saham. Secara keseluruhan, baik likuiditas, solvabilitas dan probabilitas PT. HM Sampoerna tergolong perusahaan dengan kesehatan keuangan yang baik (Saputra, 2019).

Menurut (Mu'arifin, 2020) dalam penelitiannya yang menggunakan metode deksriptif kuantitatif dengan cara mengumpulkan informasi sebanyak banyaknya dan menganalisanya kemudian mentabulasikan agar bisa menentukan perusahaan tersebut dikategorikan sehat atau tidak. Untuk data sekunder berupa laporan keuangan perusahaan yang di publish di dalam internet.

Dari beberapa penelitian-penelitian terdahulu yang sudah di paparkan diatas dapat disimpulkan bahwa dari sebagian penelitian tersebut belum sepenuhnya mengunakan pengukuran secara mendalam, metode-metode pengukuran belum sepenuhnya digunakan diantaranya metode pengukuran dengan rentabilitas, likuiditas, dan solvabilitas hanya sedikit yang mengunakan pengukuran secara penuh. Maka dari penelitian ini peneliti mengkajinya lebih mendalam mulai dari pengukuran nilai perusahaan bersasarkan analisa rentabilitas, likuiditas, sampai dengan pengukuran solvabilitas serta akan digambarkan dengan nilai persentase dan penjelasan yang mendetail (Arfa \& Marpaung, 2016).

Kinerja keuangan merupakan gambaran dari pencapaian keberhasilan perusahaan dapat diartikan sebagai hasil yang telah dicapai atas berbagai aktivitas yang telah dilakukan. Dapat dijelaskan bahwa kinerja keuangan adalah suatu analisis yang dilakukan untuk melihat sejauh mana suatu perusahaan telah melaksanakan dengan menggunakan aturan-aturan pelaksanaan keuangan secara baik dan benar (Irham, 2012). Kinerja keuangan adalah hasil atau prestasi yang telah dicapai oleh manajemen perusahaan dalam mengelola aset perusahaan secara efektif selama periode tertentu. Kinerja keuangan sangat dibutuhkan oleh perusahaan untuk mengetahui dan mengevaluasi tingkat keberhasilan perusahaan berdasarkan aktivitas keuangan yang telah dilaksanakan (Rudianto, 2013).

Menurut (Winati, 2014) Kemampuan perusahaan dalam menghasilkan keuntungan adalah kunci keberhasilan perusahaan untuk dapat dikatakan mempunyai kinerja perusahaan yang baik, karena keuntungan merupakan komponen laporan keuangan yang digunakan sebagai alat untuk menilai baik tidaknya kinerja perusahaan. Salah satu faktor yang dapat menunjukkan bagaimana kinerja perusahaan itu baik atau tidak yaitu dengan analisis laporan keuangan.

Pengertian laporan keuangan menurut (Feriansyah \& Sakti, 2015) Laporan keuangan merupakan tindakan pembuatan ringkasan dan keuangan perusahaan. Laporan keuangan ini disusun dan ditafsirkan untuk kepentingan manajemen dan pihak lain yang 
menaruh perhatian atau mempunyai kepentingan dengan data keuangan perusahaan. Sedangkan menurut (Harahap, 2015), "laporan keuangan menggambarkan kondisi keuangan dan hasil usaha suatu perusahaan pada saat tertentu atau jangka waktu tertentu".

Menurut (Aprianti, 2014) "Diduga kinerja keuangan PT. Surya Teguh Perkasa Samarinda dilihat dari rasio likuiditas, solvabilitas dan rentabilitas pada tahun 2012 semakin baik dibandingkan pada tahun 2011 dan 2010". Alat analisis yang digunakan dalam penelitian nya asalah analisis rasio keuangan yaitu: rasio likuditas dibagi menjadi Current Ratio, Acid Test Ratio dan Cash Ratio, rasio solvabilitas dibagi menjadi Debt to Asset Ratio dan Debt to Equity Ratio dan rasio rentabilitas dibagi menjadi Return On Asset dan Return On Equity. Dari hasil analisis yang diperoleh bahwa analisis kinerja keuangan pada tahun 2012 lebih baik dibandingkan tahun 2011 dan 2010. Disebabkan kenaikan laba usaha dan meningkatnya aktiva lancar dan kas serta bank bertambah.

Penelitian ini dilakukan agar dapat membantu perusahaan dalam mengambil keputusan yang baik serta menjadi refrensi bagi penelitian selanjutnya untuk dapat meneliti lebih mendalam dengan mengunakan analisa metode pengukuran yang berbeda.

Berdasarkan latar belakang di atas, maka penulis tertarik untuk membahas artikel ini dengan judul "Analisis Kinerja Keuangan Perusahaan Ditinjau Dari Rentabilitas, Likuiditas Dan Solvabilitas (Studi Kasus Pada PT Sentul City Tbk Dan Entitas Anak Tahun 2018-2019).

Tujuan dari penelitian ini adalah untuk menganalisis kinerja keuangan PT Sentul City Tbk dan entitas anak pada tahun 2018-2019 ditinjau dari rentabilitas, likuiditas, dan solvabilitas serta untuk mengetahui pengaruh rentabilitas, likuiditas dan solvabilitas terhadap Nilai Perusahaan baik secara simultan maupun parsial.

\section{Metode Penelitian}

\section{Jenis Penelitian}

Penelitian ini merupakan penelitian dengan menggunakan metode kuantitatif dan juga metode deskriptif, yaitu data yang berbentuk angka pasti serta menganalisis data-data laporan keuangan dari perusahaan tersebut, yang kemudian hasil penelitiannya digunakan untuk mengetahui seberapa besar pengaruh analisa likuiditas, solvabilitas dan rentabilitas terhadap nilai perusahaan. Data laporan keuangan yang digunakan yaitu laporan PT Sentul City Tbk periode taahun 20182019.

\section{Metode Pengumpulan Data}

Metode pengumpulan data yang digunakan adalah metode kuantitatif dan metode deskriptif, yaitu dengan meninjau, meneliti, serta menjabarkan laporan keuangan untuk menganalisis pengaruh likuiditas, solvabilitas, rentabilitas, serta indikator-indikator lainnya yang dapat mempengaruhi kinerja keuangan dari perusahaan tersebut. 


\section{Hasil dan Pembahasan}

\section{A. Hasil Penelitian}

Berdasarkan hasil analisis serta perhitungan yang dikemukakan secara deskriptif dengan metode kuantitatif yang menemukan bahwa:

- Likuiditas yang diukur dengan Current Ratio dan Quick Ratio

Likuiditas yang diukur dengan Current Ratio dan Quick Ratio ini dapat menggambarkan suatu perusahaan tersebut apakah memiliki kemampuan untuk memenuhi kewajibannya baik jangka pendek maupun jangka panjang dengan menggunakan aset yang paling likuid. Dari hasil analisis dengan menggunakan metode ini, PT Sentul City Tbk menunjukkan rasio diatas $1 \%$ yang artinya perusahaan ini dalam kondisi yang baik.

- Solvabilitas yang diukur dengan Debt to Asset Ratio dan Debt to Equity ratio Solvabilitas yang diukur dengan Debt to Asset Ratio dan Debt to Equity ratio ini menunjukan seberapa besar aset yang dibiayai oleh hutang serta menunjukkan apakah perusahaan tersebut memiliki manajemen keuangan yang baik atau tidak dalam mengelola aktivitas investasinya. Dari hasil penelitian ini menemukan bahwa PT Sentul City Tbk pada laporan keuangan tahun 2019 hanya 36\% aset saja yang biayai oleh hutang serta perusahaan ini memiliki tingkat hutang yang lebih rendah dari pada ekuitasnya. Berdasarkan analisis yang diperoleh dari kedua rasio ini dapat disimpulkan bahwa PT Sentul City Tbk dalam kondisi yang baik.

- Rentabilitas yang diukur dengan Gross Profit Margin dan Net Profit Margin Rentabilitas yang diukur dengan Gross Profit Margin dan Net Profit Margin ini merupakan rasio profitabilitas marjin laba kotor dan marjin laba bersih dari suatu perusahaan. Hasil analisis dari perusahaan ini menunjukkan bahwa perusahaan memiliki lebih dari 50\% pendapatan yang tersisa setelah membayar beban pokoknya, serta perusahaan ini mendapatkan 39\%-42\% pendapatan dari hasil penjualan bersihnya. Dari hasil analisis ini dapat disimpulkan bahwa keadaan perusahaan berada dalam kategori yang baik.

Berdasarkan hasil analisis di atas dapat disimpulkan bahwa metede pengukuran yang digunakan diantaranya Likuiditas, Solvabilitas dan Rentabilitas sangat berpengaruh terhadap nilai perusahaan.

\section{B. Pembahasan}

\section{Likuiditas}

Likuiditas adalah kemampuan suatu perusahaan dalam memenuhi semua kewajiban jangka pendeknya. Secara spesifik likuiditas mencerminkan ketersediaan dana yang dimiliki oleh perusahaan untuk memenuhi semua hutang yang akan segera jatuh tempo.

a. Likuiditas diukur dengan Current Ratio

Current Ratio (Rasio Lancar) merupakan rasio untuk mengukur kemampuan perusahaan untuk membayar kewajiban jangka pendek atau hutang yang segera 
jatuh tempo pada saat ditagih secara keseluruhan. Dengan kata lain, seberapa banyak aktiva lancar yang tersedia untuk menutupi kewajiban jangka pendek yang segera jatuh tempo. Rasio lancar dapat pula dikatakan sebagai bentuk untuk mengukur tingkat keamanan (margin of safety) suatu perusahaan.

$$
\text { Current Ratio }=\frac{\text { Aset Lancar } / \text { Current Assets }}{\text { Hutang Lancar / Current Liabilities }} \times 100 \%
$$

Perhitungan pada Laporan Keuangan PT Sentul City Tbk per 31 Desember 2018 dan 30 Juni 2019

- $\quad$ Periode 31 Desember 2018

$$
\text { Current Ratio }=\frac{4.547 .349 .270 .546}{3.093 .284 .238 .071} \times 100 \%=1,47 \%
$$

Periode 30 Juni 2019

$$
\text { Current Ratio }=\frac{4.868 .740 .653 .110}{3.529 .452 .317 .987} \times 100 \%=1,38 \%
$$

Dari perhitungan di atas, terjadi penurunan tingkat Current Ratio sebesar 0,09\% pada periode 30 Juni 2019. Tetapi, dari kedua periode tersebut dapat disimpulkan bahwa perusahaan mempunyai kemampuan untuk melunasi kewajibannya.

Rumus tingkat pengukuran Likuiditas diukur dengan Current Ratio sudah sesuai dengan standar tingkat pengukuran kinerja keuangan SK Menteri Keuangan RI No.826/KMK.013/1992 dan menurut (Kasmir, 2012).

b. Likuiditas Diukur Dengan Quick Ratio

Quick Ratio (Rasio Cepat) adalah rasio yang digunakan untuk mengukur kemampuan perusahaan untuk memenuhi kewajiban jangka pendeknya dengan menggunakan aset yang paling likuid atau aset yang paling mendekati uang tunai (aset cepat).

$$
\text { Quick Ratio }=\frac{\text { Aktiva Lancar }- \text { Persediaan }}{\text { Hutang Lancar / Current Liabilities }}
$$

Perhitungan pada Laporan Keuangan PT Sentul City Tbk per 31 Desember 2018 dan 30 Juni 2019

- $\quad$ Periode 31 Desember 2018

$$
\text { Quick Ratio }=\frac{4 \cdot 547 \cdot 349 \cdot 270 \cdot 546-2.472 \cdot 251 \cdot 932 \cdot 904}{3 \cdot 093 \cdot 284 \cdot 238 \cdot 071}=0,67
$$


Analisis Kinerja Keuangan Perusahaan Ditinjau dari Rentabilitas, Likuiditas dan

- $\quad$ Periode 30 Juni 2019

$$
\text { Quick Ratio }=\frac{4.868 \cdot 740 \cdot 653 \cdot 110-2.714 .463 .338 \cdot 308}{3 \cdot 529 \cdot 452.317 .987}=0,61
$$

Dari perhitungan di atas, terjadi penurunan tingkat Qick Ratio sebesar 0,06 pada periode 30 Juni 2019. Dari perhitungan kedua periode di atas dapat disimpulkan bahwa perusahaan menunjukkan kemampuan yang kurang baik dalam melunasi kewajibannya.

Rumus tingkat pengukuran Likuiditas diukur dengan Quick Ratio sudah sesuai dengan standar tingkat pengukuran kinerja keuangan SK Menteri Keuangan RI No.826/KMK.013/1992 dan menurut (Kasmir, 2012).

\section{Solvabilitas}

Solvabilitas adalah menunjukkan kemampuan perusahaan untuk memenuhi kewajiban keuangannya apabila perusahaan tersebut dilikuidasikan, baik kewajiban keuangan jangka pendek maupun jangka panjang.

a. Solvabilitas Diukur Dengan Debt to Asset Ratio

Deb to Asset Ratio (DAR) adalah sebuah rasio untuk mengukur jumlah aset yang dibiayai oleh hutang. Rasio ini juga sangat penting untuk melihat solvabilitas perusahaan.

Semakin tinggi nilai DAR ini mengindikasikan :

- Semakin besar jumlah aset yang dibiayai oleh hutang.

- Semakin kecil jumlah aset yang dibiayai oleh modal.

- Semakin tinggi resiko perusahaan untuk menyelesaikan kewajiban jangka panjang.

$$
\text { Debt to Asset Ratio }=\frac{\text { Total Hutang }}{\text { Total Aset }} \times 100 \%
$$

Perhitungan pada Laporan Keuangan PT Sentul City Tbk per 31 Desember 2018 dan 30 Juni 2019

- $\quad$ Periode 31 Desember 2018

$$
\text { Debt to Asset Ratio }=\frac{5.631 .606 .614 .993}{16.252 .732 .184 .207} \times 100 \%=0,35 \%
$$

Debt to Asset Ratio periode 31 Desember 2018 adalah 35\% yang artinya $35 \%$ aset yang dimiliki dibiayai oleh hutang sedangkan $65 \%$ sisanya dibiayai oleh modal. Dapat disimpulkan bahwa Solvabilitas perusahaan berdasarkan Debt to Asset Ratio dalam keadaan baik untuk bisa melunasi semua kewajiban yang ada. 
Hidayatul mu'arifin dan Peri Irawan

- Periode 30 Juni 2019

$$
\text { Debt to Asset Ratio }=\frac{6.071 .554 .578 .523}{16.734 .318 .903 .108} \times 100 \%=0,36 \%
$$

Debt to Asset Ratio periode 30 Juni 2019 adalah 36\% yang artinya 36\% aset yang dimiliki dibiayai oleh hutang sedangkan 64\% sisanya dibiayai oleh modal. Dapat disimpulkan bahwa Solvabilitas perusahaan berdasarkan Debt to Asset Ratio dalam keadaan baik untuk bisa melunasi semua kewajiban yang ada. Meskipun jumlah ini lebih besar dari periode sebelumnya tetapi perbedaannya sangat sedikit, jadi tidak terlalu berpengaruh pada keadaan keuangan perusahaan.

Rumus tingkat pengukuran Solvabilitas Diukur Dengan Debt to Asset Ratio sudah sesuai dengan standar tingkat pengukuran kinerja keuangan SK Menteri Keuangan RI No.826/KMK.013/1992. dan menurut (Kasmir, 2012).

b. Solvabilitas Diukur Dengan Debt to Equity Ratio

Debt to Equity Ratio (Rasio Hutang terhadap Ekuitas atau Rasio Hutang Modal) adalah suatu rasio keuangan yang menunjukan proporsi relatif antara Ekuitas dan Hutang yang digunakan untuk membiayai aset perusahaan. Rasio Debt to Equity ini juga dikenal sebagai Rasio Leverage (Rasio Pengungkit) yaitu rasio yang digunakan untuk mengukur seberapa baik struktur investasi suatu perusahaan.

$$
\text { Debt to Equity Ratio }=\frac{\text { Total Hutang }}{\text { Ekuitas }}
$$

Perhitungan pada Laporan Keuangan PT Sentul City Tbk per 31 Desember 2018 dan 30 Juni 2019

- $\quad$ Periode 31 Desember 2018

$$
\text { Debt to Equity Ratio }=\frac{5.631 \cdot 606.614 .993}{10.621 .125 .569 .214}=0,53
$$

- Periode 30 Juni 2019

$$
\text { Debt to Equity Ratio }=\frac{6 \cdot 071.554 .578 .523}{10.662 .764 .324 .585}=0,57
$$


Dari perhitungan kedua periode di atas, perusahaan memiliki tingkat hutang yang lebih rendah daripada ekuitas perusahaan dan dapat disimpulkan bahwa perusahaan dalam keadaan baik.

Rumus tingkat pengukuran Solvabilitas diukur dengan Debt to Equity Ratio sudah sesuai dengan standar tingkat pengukuran kinerja keuangan SK Menteri Keuangan RI No.826/KMK.013/1992. dan menurut (Kasmir, 2012).

\section{Rentabilitas}

Rentabilitas adalah kemampuan perusahaan dalam menghasilkan keuntungan dengan semua modal yang bekerja didalamnya.

a. Rentabilitas Diukur Dengan Gross Profit Margin Ratio

Gross Profit Margin (Marjin Laba Kotor) adalah rasio profitabilitas yang digunakan untuk menghitung persentase kelebihan laba kotor terhadap pendapatan penjualan. Gross Profit atau Laba Kotor yang dimaksud disini adalah pendapatan Penjualan yang dikurangi dengan Harga Pokok Penjualan (HPP).

$$
\text { Gross Profit Margin }=\frac{\text { Laba Kotor }}{\text { Pendapatan Penjualan }}
$$

Perhitungan pada Laporan Keuangan PT Sentul City Tbk per 30 Juni 2018 dan 30 Juni 2019

- $\quad$ Periode 30 Juni 2018

$$
\text { Gross Profit Margin }=\frac{353 \cdot 638.409 .593}{545.188 .756 .048}=0,65
$$

Dari perhitungan di atas didapat bahwa Gross Profit Margin pada periode 30 Juni 2018 adalah sebesar 65\%, yaitu perusahaan memiliki 65\% dari pendapatan yang tersisa setelah melunasi semua beban pokok yang terkait. Dari pernyataan ini dapat disimpulkan bahwa perusahaan memiliki Gross Profit Margin yang cukup tinggi yang berarti perusahaan ini mampu menjalankan bisnisnya secara efisien karena tingkat beban pokoknya lebih rendah dari pendapatan perusahaan.

Rumus tingkat pengukuran Rentabilitas diukur dengan Gross Profit Margin Ratio sudah sesuai dengan standar tingkat pengukuran kinerja keuangan SK Menteri Keuangan RI No.826/KMK.013/1992. dan menurut (Kasmir, 2012)

- $\quad$ Periode 30 Juni 2019

$$
\text { Gross Profit Margin }=\frac{230.540 .225 .060}{390.347 .741 .632}=0,59
$$


Dari perhitungan di atas didapat bahwa Gross Profit Margin pada periode 30 Juni 2019 adalah sebesar 59\%, turun 6\% dari tahun lalu. Meskipun begitu, perusahaan masih memiliki 59\% dari pendapatan yang tersisa setelah melunasi semua beban pokok yang terkait. Dari pernyataan ini dapat disimpulkan bahwa perusahaan memiliki tingkat Gross profit Margin yang relatif tinggi dan dapat dikategorikan perusahaan ini dalam menjalankan bisnisnya secara efisien karena beban pokonya lebih rendah dari pendapatan perusahaan.

Rumus tingkat pengukuran rentabilitas diukur dengan gross profit margin ratio sudah sesuai dengan standar tingkat pengukuran kinerja keuangan SK Menteri Keuangan RI No.826/KMK.013/1992. dan menurut Kasmir (2012).

a. Rentabilitas Diukur Dengan Net Profit Margin Ratio

Net Profit Margin (Marjin Laba Bersih) adalah rasio profitabilitas yang digunakan untuk mengukur persentase laba bersih pada suatu perusahaan terhadap penjualan bersihnya. Marjin Laba Bersih ini menunjukan proporsi penjualan yang tersisa setelah dikurangi semua biaya terkait.

$$
\text { Net Profit Margin }=\frac{\text { Net Profit } / \text { Pendapatan Bersih }}{\text { Net Sales } / \text { Penjualan Bersih }}
$$

Perhitungan pada Laporan Keuangan PT Sentul City Tbk per 30 Juni 2018 dan 30 Juni 2019

- $\quad$ Periode 30 Juni 2018

$$
\text { Net Profit Margin }=\frac{51 \cdot 075 \cdot 253 \cdot 604}{130 \cdot 152 \cdot 834 \cdot 776}=0,39
$$

Dari perhitungan di atas, tingkat Net Profit Margin yang dimiliki oleh perusahaan adalah sebesar 39\%. Artinya bahwa perusahaan dalam keadaan baik dengan berhasil mengendalikan biaya dengan baik.

- $\quad$ Periode 30 Juni 2019

$$
\text { Net Profit Margin }=\frac{41 \cdot 132 \cdot 491 \cdot 272}{97 \cdot 334 \cdot 435 \cdot 800}=0,42
$$

Dari perhitungan di atas, tingkat Net Profit Margin yang dimiliki oleh perusahaan relatif sangat tinggi sebesar $42 \%$. Artinya bahwa perusahaan saat ini dalam kondisi yang sangat baik dengan mampu mengendalikan biaya dengan sangat baik.

Rumus tingkat pengukuran Rentabilitas diukur dengan Gross Profit Margin Ratio sudah sesuai dengan standar tingkat pengukuran kinerja keuangan SK Menteri Keuangan RI No.826/KMK.013/1992. dan menurut (Kasmir, 2012). 


\section{Kesimpulan}

Berdasarkan hasil penelitian yang di tulis dalam penelitin ini, maka penulis mengambil kesimpulan bahwa Tingkat Pengukuran kinerja keuangan dengan Likuiditas, Solvabilitas dan Rentabilitas dapat mempengaruhi Nilai Perusahaan. Diantaranya:

Pada tingkat Likuiditas berdasarkan Current Ratio terjadi penurunan tingkat Current Ratio sebesar 0,09\% pada periode 30 Juni 2019 artinya bahwa perusahaan mempunyai kemampuan untuk melunasi kewajibannya, Likuiditas diukur dengan Quick Ratio terhadap Nilai Perusahaan terjadi penurunan tingkat Quick Ratio sebesar 0,06 pada periode 30 Juni 2019 artinya bahwa perusahaan menunjukkan kemampuan yang kurang baik dalam melunasi kewajibannya.

Pada tingkat Solvabilitas berdasarkan Debt to Asset Ratio periode tahun 2018 adalah $35 \%$ yang artinya $35 \%$ aset yang dimiliki dibiayai oleh hutang sedangkan $65 \%$ sisanya dibiayai oleh modal dan pada tahun 2019 adalah $36 \%$ yang artinya $36 \%$ aset yang dimiliki dibiayai oleh hutang sedangkan 64\% sisanya dibiayai oleh modal. bahwa Solvabilitas perusahaan berdasarkan Debt to Asset Ratio dalam keadaan baik untuk bisa melunasi semua kewajiban yang ada. Pada Solvabilitas diukur dengan Debt to Equity Ratio terhadap Nilai Perusahaan pada tahun 2018 adalah 0,53 dan tahun 2019 0,57 artinya perusahaan memiliki tingkat hutang yang lebih rendah daripada ekuitas perusahaan serta menunjukan bahwa perusahaan dalam keadaan baik.

Pada tingkat Rentabilitas diukur dengan Gross Profit Margin Ratio pada tahun 2018 adalah sebesar $65 \%$, yaitu perusahaan memiliki 65\% dari pendapatan yang tersisa setelah melunasi semua beban pokok yang terkait. artinya perusahaan memiliki Gross Profit Margin yang cukup tinggi yang berarti perusahaan ini mampu menjalankan bisnisnya secara efisien karena tingkat beban pokoknya lebih rendah dari pendapatan perusahaan. Dan pada tahun 2019 sebesar 59\%, turun 6\% dari tahun 2018. Meskipun begitu, perusahaan masih memiliki 59\% dari pendapatan yang tersisa setelah melunasi semua beban pokok yang terkait.

Pada tingkat Rentabilitas diukur dengan Net Profit Margin Ratio tahun 2018 tingkat Net Profit Margin yang dimiliki oleh perusahaan adalah sebesar 39\%. Artinya bahwa perusahaan dalam keadaan baik dengan berhasil mengendalikan biaya dengan baik. Dan untuk tahun 2019 tingkat Net Profit Margin yang dimiliki oleh perusahaan adalah sebesar $42 \%$. Artinya bahwa perusahaan saat ini dalam kondisi yang sangat baik dengan mampu mengendalikan biaya dengan sangat baik. 
Hidayatul mu'arifin dan Peri Irawan

\section{BIBLIOGRAFI}

Agus Sartono. (2012). Manajemen Keuangan Teori dan Aplikasi Edisi4. Yogyakarta: BPFE.

Aprianti, Rury. (2014). Analisis Kinerja Keuangan Ditinjau Dari Aspek Likuiditas, Solvabilitas Dan Rentabilitas Pada PT. Surya Teguh Perkasa Samarinda. Ejournal Ilmu Administrasi Bisnis Vol 2 (3).

Arfa, Faisal Ananda, \& Marpaung, Watni. (2016). Metodologi Penelitian Hukum Islam. Kencana.

Atmadjati, Arista. (2018). Layanan Prima Dalam Praktik Saat Ini. Deepublish.

Budiawan, Prima. (2009). Analisis Kinerja Keuangan Perusahaan Ditinjau dari Rentabilitas, Likuiditas dan Solvabilitas (Studi Kasus Pada PTPN X Surakarta). Universitas Muhammadiyah Surakarta.

Feriansyah, Khoirul, \& Sakti, Arya Mahendra. (2015). Studi Komparatif Laju Korosi Logam Kuningan C3604 (Spuyer Karburator) Di Media Premium Dan Pertamax Menggunakan Metode ASTM D-130. Fakultas Teknik: Universitas Negeri Surabaya.

Harahap, Dedy Ansari. (2015). Analisis faktor-faktor yang mempengaruhi keputusan pembelian konsumen di Pajak USU (PAJUS) Medan. Jurnal Keuangan Dan Bisnis, 7(3), 227-242.

Irham, Fahmi. (2012). Analisis laporan keuangan. Bandung: Alfabeta.

Kasmir. (2012). Analisis Laporan Keuangan (Cetakan Ke). Jakarta: Rajawali Pers.

Mu'arifin, Hidayatul. (2020). Analisis Prediksi Kebangkrutan Dengan Menggunakan Metode Altman (Z Score) Pada Perusahaan Textile Dan Garmen Pada Tahun 20172019. Proseding Seminar Nasional Akuntansi, 3(1).

Pongoh, Marsel. (2013). Analisis Laporan Keuangan untuk Menilai Kinerja Keuangan PT. Bumi Resources Tbk. Jurnal EMBA: Jurnal Riset Ekonomi, Manajemen, Bisnis Dan Akuntansi, 1(3).

Rudianto, Edi. (2013). Akuntansi Manajemen Informasi Untuk Pengambilan Keputusan Strategis. Jakarta: Erlangga.

Saputra, Yoga. (2019). Analisis Kinerja Keuangan Perusahaan Ditinjau dari Likuiditas, Solvabilitas dan Rentabilitas pada PT HM Sampoerna Tbk pada Tahun 20152017.

Sutrisno. (2012). Manajemen Keuangan Teori Konsep dan Aplikasi. Yogyakarta: Ekonisia. 
Analisis Kinerja Keuangan Perusahaan Ditinjau dari Rentabilitas, Likuiditas dan Solvabilitas

Winati, Ayu Wulan. (2014). Penilaian Kinerja Keuangan Pada Pt. Kaltim Adhiguna Muatan Berdasarkan Analisis Rasio Likuiditas, Solvabilitas, Aktivitas Dan Profitabilitas. Jurusan Akuntansi Universitas Dian Nuswantoro Semarang, . 